Article

\title{
Improvement of Heavy Rainfall Simulated with SST Adjustment Associated with Mesoscale Convective Complexes Related to Severe Flash Flood in Luwu, Sulawesi, Indonesia
}

\author{
Erma Yulihastin ${ }^{1, *(\mathbb{D})}$, Danang Eko Nuryanto ${ }^{2}$, Trismidianto ${ }^{1}(\mathbb{D})$ and Robi Muharsyah ${ }^{2}(\mathbb{D})$ \\ 1 Center of Atmospheric Research and Technology, National Research and Innovation Agency, \\ Bandung 40173, Indonesia; trismidianto@brin.go.id \\ 2 Research and Development Center, Indonesian Agency for Meteorology Climatology and Geophysics, \\ Jakarta 10720, Indonesia; danang.eko@bmkg.go.id (D.E.N.); robi.muharsyah@bmkg.go.id (R.M.) \\ * Correspondence: erma.yulihastin@brin.go.id
}

check for updates

Citation: Yulihastin, E.; Nuryanto, D.E.; Trismidianto; Muharsyah, R. Improvement of Heavy Rainfall Simulated with SST Adjustment Associated with Mesoscale Convective Complexes Related to Severe Flash Flood in Luwu, Sulawesi, Indonesia. Atmosphere 2021, 12, 1445. https://doi.org/10.3390/ atmos12111445

Academic Editor: Anthony R. Lupo

Received: 4 September 2021

Accepted: 29 October 2021

Published: 1 November 2021

Publisher's Note: MDPI stays neutral with regard to jurisdictional claims in published maps and institutional affiliations.

Copyright: (c) 2021 by the authors. Licensee MDPI, Basel, Switzerland. This article is an open access article distributed under the terms and conditions of the Creative Commons Attribution (CC BY) license (https:/ / creativecommons.org/licenses/by/ $4.0 /)$.

\begin{abstract}
Flash flooding is an important issue as it has a devastating impact over a short time and in a limited area. However, predicting flash floods is challenging because they are connected to convection systems that rapidly evolve and require a high-resolution forecasting system. In addition, modeling a case study of a mesoscale convective complex (MCC) is the key to improving our understanding of the heavy rainfall systems that trigger flash floods. In this study, we aim at improving modeling skills to simulate a heavy rainfall system related to flash-flood-producing MCCs. We simulated a heavy rainfall event related to a severe flash flood in Luwu, Sulawesi, Indonesia, on 13 July 2020. This flood was preceded by persistent heavy rainfall from 11 to 13 July 2020. In this case, we investigated the role of sea surface temperature (SST) in producing the persistent heavy rainfall over the region. Therefore, we explore the physical and dynamic processes that caused the heavy rainfall using a convection-permitting model with $1 \mathrm{~km}$ resolution and an experiment comparing the situation with and without updated SST. The results show that the heavy rainfall was modulated by the development of a pair of MCCs during the night. The pair of MCCs was triggered by a meso-low-pressure system with an anti-cyclonic circulation anomaly over the Makassar Strait and was maintained by the warm front passing between the sea and land over central Sulawesi. This front was characterized by moist-warm and cold-dry low-level air, which may have helped extend the lifetime of the MCCs. The north-westward propagation of the MCCs was due to the interaction between predominantly a south-easterly monsoon and SST anomalies. This study suggested that the long-lived ( $>10 \mathrm{~h}$ ) MCCs ( $>80,000 \mathrm{~km}^{2}$ cloud shield) and persistent precipitation are reproduced well in the updated SST scenario in the WRF model. This relatively simple technique in the running model provides a new strategy for improving flash flood forecasting by better predicting rainfall as an input in the hydrological model. Our findings also indicated a long-lived MCC maintained by back-building mechanisms from night to morning inland as an exceptional MCC, which does not correspond to a previous study.
\end{abstract}

Keywords: flash flood; mesoscale convective complex; heavy rainfall; warm front; sea surface temperature

\section{Introduction}

Flash flooding is the most hazardous weather-related event with a tremendous impact on affected areas, leading to infrastructure destruction and loss of life [1,2]. On 13 July 2020 at around 20:00 LST, a major flash flood hit Luwu, Sulawesi, Indonesia, and killed 38 people, injured 58 people, and led to the evacuation of 14,483 others, while a further 40 people were missing [3]. The flood was triggered by persistent heavy rainfall from 11 to 13 July 2020. This extreme event occurred during the dry season (July-August) in Indonesia and was strongly influenced by the Australian winter monsoon. However, several parts of eastern 
Indonesia (i.e., parts of Sulawesi, Maluku) have different annual and seasonal rainfall characteristics [4], which are strongly determined by the eastern route of the Indonesian Throughflow (ITF) and are related to warm sea surface temperatures (SSTs) [5]. The SST variability in the eastern Indonesian seas during June, July, and August (JJA) is determined by the south-easterly winds, which lead to cold SSTs in the Arafura Sea and warm SSTs in the Banda Sea [6]. A recent study identified that SST and rainfall are positively correlated across the central and eastern Indonesia seas $\left(5^{\circ} \mathrm{S}-5^{\circ} \mathrm{N}, 115^{\circ} \mathrm{E}-135^{\circ} \mathrm{E}\right)$ and are associated with an anticyclonic circulation at $850 \mathrm{hPa}$, which coincides with significant convergence over the regions [7].

The influence of the eastern Indonesian seas (i.e., the Maluku Sea and the Arafura Sea) on rainfall intensities along the ITF pathway is determined by the warmer SSTs in the western Pacific [8]. Hence, during La Niña episodes, the warmer seas enhance the development of cumulus congestus clouds [8] and consequently increase the frequency $[9,10]$, amount, and intensity of extreme rainfall over eastern Indonesia (i.e., Sulawesi, Maluku, Ambon, Papua) in JJA [11]. Considering the increase in the frequency of extreme La Niña episodes under various global warming scenarios [12], the frequency of extreme events associated with severe rainfall may be enhanced in eastern Indonesia (i.e., Sulawesi); however, the dynamic processes causing extreme rainfall at regional and local scales over eastern Indonesia have not been well addressed, owing to the limitations of numerical studies performed at storm-resolving resolutions.

The diurnal cycle of tropical convection over eastern Indonesia during JJA is controlled primarily by local seas (i.e., the Maluku Sea and Arafura Sea), which are directly connected to the warm pool in the Northwest Pacific. The diurnal rainfall over the Northwest Pacific typically reaches a maximum from the morning to the night-time, and heavy rainfall is particularly very frequent in July and August [13]. This rainfall is created by deep convective clouds reaching up to $7-8 \mathrm{~km}$ in depth. The convective activity is mainly caused by a double peak due to latent heat, which is associated with both shallow precipitation and Mesoscale Convective Systems (MCSs) [14]. MCSs have been observed by radar as a deep mode $(5-6 \mathrm{~km})$ that develops from stratiform precipitation [14].

Due to the hypothesis that MCSs over the Northwest Pacific could extend as far as the eastern Indonesian seas, they may have had an influence on the extreme precipitation that may have triggered the flash floods in Luwu, Sulawesi on 13 July 2020. As a sudden-release event, a flash flood could be triggered by excessive rainfall, primarily characterized by the rapid onset of rainfall, i.e., less than six hours [1]. The intense rainfall is mainly associated with the disturbance of mesoscale weather systems, with the horizontal scale ranging from tens to thousands of kilometers [15].

Hence, as Luwu is located in central Sulawesi, which has a rugged topography (see Figure 1, 1200-2000 m) and is surrounded mostly by various bodies of water (Malaka Strait, Pacific Ocean, Maluku Sea, Bone Bay), this is an ideal case that represents a complex terrain. In this study, we expect to acquire valuable knowledge toward improving modeling skills to simulate a flash-flood-producing heavy rainfall system over complex terrain. Although research on flash flooding has involved multidisciplinary subjects in the past two decades, developing a capable and reliable model is still a considerable challenge for the scientific community as a whole. 


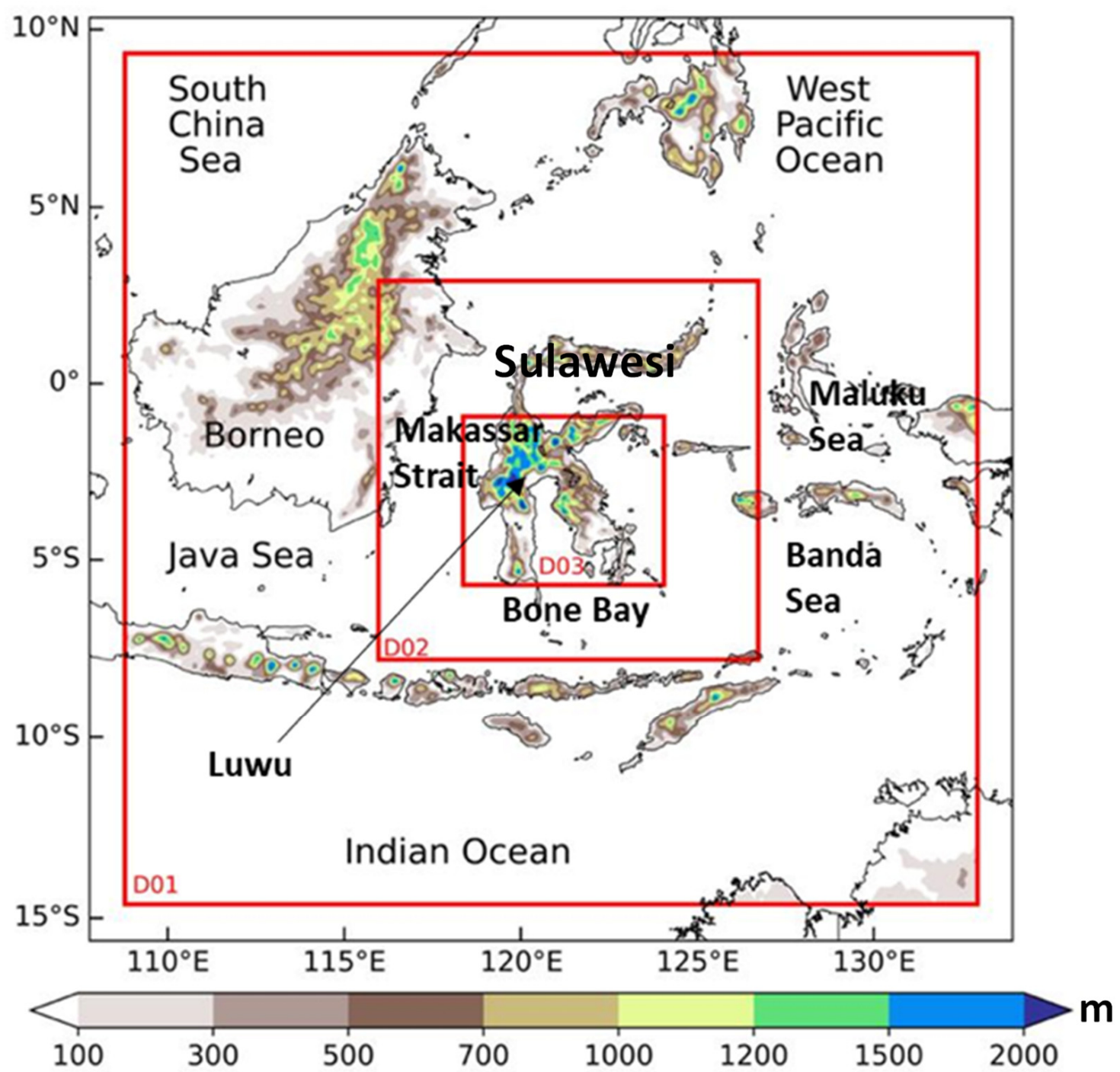

Figure 1. Simulation domain of the WRF model. Red boxes represent domains D01, D02, and D03, with resolutions of $9 \mathrm{~km}$, $3 \mathrm{~km}$, and $1 \mathrm{~km}$, respectively. Color shading shows the terrain height.

Due to the limited observation over eastern Indonesia and the course of the satellite data, a real numerical case study is a suitable method to investigate physical and dynamic processes that caused a flash-flood-producing heavy rainfall over Luwu, Sulawesi, Indonesia. Furthermore, by using the Weather Research and Forecasting (WRF) model at a $1 \mathrm{~km}$ spatial resolution through an experiment scenario with updated SST as the model input, we expect to provide an efficient method to improve the rainfall prediction product by adjusting the initial data conditions.

\section{Materials and Methods}

\subsection{Studied Area, Simulation Domains, and Episodes Selected}

We used the WRF version 4.1.2 [16] with one-way nested domains, comprising a coarse domain (D01), inner domain (D02), and the innermost domain (D03), which have a spatial resolution of $9 \mathrm{~km}, 3 \mathrm{~km}$, and $1 \mathrm{~km}$, respectively (Figure 1). The center of the coarse domain is $2.702^{\circ} \mathrm{S}, 120.859^{\circ} \mathrm{E}$. The Mercator map projection is used for the model domains. The simulation configurations and physical parameterizations are summarized in Table 1. 
Table 1. WRF model configuration for simulating precipitation in eastern Indonesia.

\begin{tabular}{cccc}
\hline Horizontal Resolution & $\mathbf{9 ~ K m}$ & $\mathbf{3 ~ K m}$ & $\mathbf{1 ~ K m}$ \\
\hline Number of horizontal grids & $300 \times 300$ & $400 \times 400$ & $634 \times 532$ \\
Number of vertical grids & 45 & 45 & 45 \\
Cumulus & Betts-Miller-Janjić & Betts-Miller-Janjić & - \\
Microphysic & WSM-3 & WSM-3 & WSM-3 \\
Long-wave/Short-wave & RRTM/Dhudia & RRTM/Dhudia & RRTM/Dhudia \\
radiation & Yonsei University & Yonsei University & Yonsei University \\
Boundary layer & Revised MM5 & Revised MM5 & Revised MM5 \\
Surface layer & Monin-Obukhov & Monin-Obukhov & Monin-Obukhov \\
Land surface & NOAH & NOAH & NOAH \\
\hline
\end{tabular}

We used Betts-Miller-Janjić as a cumulus scheme in the first and second domains, and a no-cumulus scheme for the third domain. These parameterization schemes, following Fonseca et al. [17], best predict the diurnal rainfall over the Maritime Continent and were proven by Yulihastin et al. [18] to be able to capture thunderstorm events in terms of timing, maximum intensity, duration, and location of precipitation. The initial and lateral boundary conditions are obtained from the global National Centers for Environmental Predictions (NCEP) Final Analysis (FNL) Operational Global Analysis data [19] and forecast grids, which have a horizontal resolution of $0.25^{\circ} \times 0.25^{\circ}$ and a temporal resolution of $6 \mathrm{~h}$. In this case study, we simulated selected episodes of heavy rainfall events from 13 to 14 July 2020 associated with a flash flood in the Luwu region, Sulawesi, Indonesia. The 3-day forecast outputs were evaluated for each PBL scheme, and the model was initialized at 00:00 UTC (07:00 LST), 11 July 2020, which is considered as an appropriate spin-up time for the model.

\subsection{Modeling Technique}

The simulations were carried out using the Advanced Research WRF (WRF-ARWv4.2.1) mesoscale model developed by the National Center for Atmospheric Research (NCAR), USA. This is a widely used community mesoscale model and a cutting-edge atmospheric modeling system that may be utilized for meteorological research as well as numerical weather prediction. The WRF's many physical choices can be combined in a variety of ways. We tried both with and without SST updates. CTL experiments are those that do not include SST updates. Our WRF experiments use the same parameterizations for microphysics, radiation (long and short wave), cumulus, surface layer, planetary boundary layer, and land surface, with the exception of SST updating. We applied the model configuration (Table 1) into namelists of both the WRF pre-processing system (WPS) and input before running the model. The detailed namelists (WPS and input) in this experiment are described in the supplemental file.

We investigated the hypothesis that SST may control the diurnal rainfall over Sulawesi Island by conducting experiments with two scenarios: (1) the default model is run without updating the SST, which is referred to as the control simulation (CTL), and (2) the model is run with the SST updated every $6 \mathrm{~h}$. This is referred to as the updated SST scenario. The CTL and SST scenario simulations were run on all domains, with a focused study in domain 3 (D03). Both experiments were conducted with consideration of the outermost domain to capture regional circulations (e.g., the wind circulation, SST, etc.), as these influence the circulation in the innermost domain.

To confirm the heavy rainfall event, we validated the simulation results using groundbased observational data from the Agency for Meteorology Climatology and Geophysics (BMKG) station [20], the Global Satellite Mapping of Precipitation (GSMaP), with $0.1^{\circ}$ spatial resolution [21]. We also used the Himawari satellite image of IR1 (infrared channel 1) for indicating convective clouds with $0.05^{\circ}$ spatial resolution [22]. We assumed that the spatial resolution of the Himawari satellite is sufficient to observe the development of a large mesoscale convective cloud, hereafter known as a mesoscale convective complex 
(MCC). The IR1 image represents the top-of-cloud temperature, hereafter called black-body temperature (TBB). Furthermore, to identify the background wind, moisture transport, specific humidity, and SST conditions, we used high-resolution near-surface ERA5 data from the European Center for Medium-Range Weather Forecasts with a spatial resolution of $0.25^{\circ} \times 0.25^{\circ}[23]$.

\section{Results and Discussion}

\subsection{Rainfall Observed and Background Conditions}

Heavy rainfall occurred from 13 to 16 July 2020 (daily average of $90-120 \mathrm{~mm} \mathrm{~d}^{-1}$ ) over the Luwu region, which has a relatively high terrain and is close to Bone Bay at its southern boundary with the Banda Sea (Figure 2a,b). On 13 July, stations recorded heavy rainfall over Luwu and the southern part of Sulawesi Island (Figure 2c).

(a)

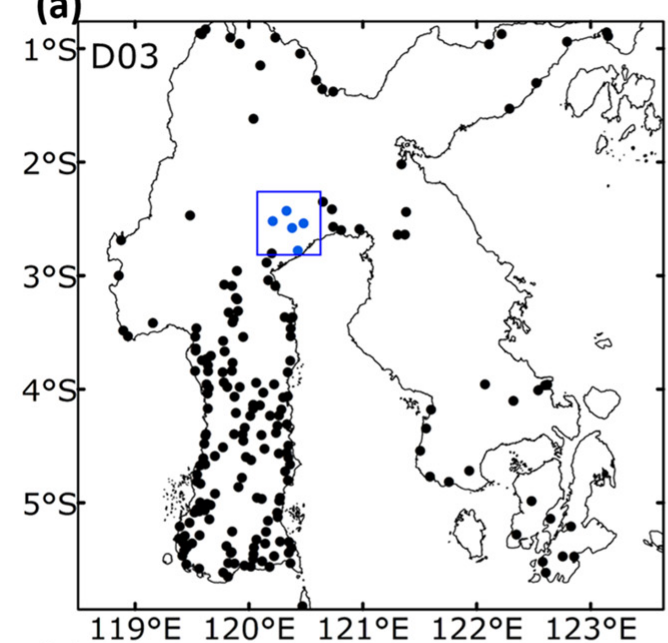

(b)

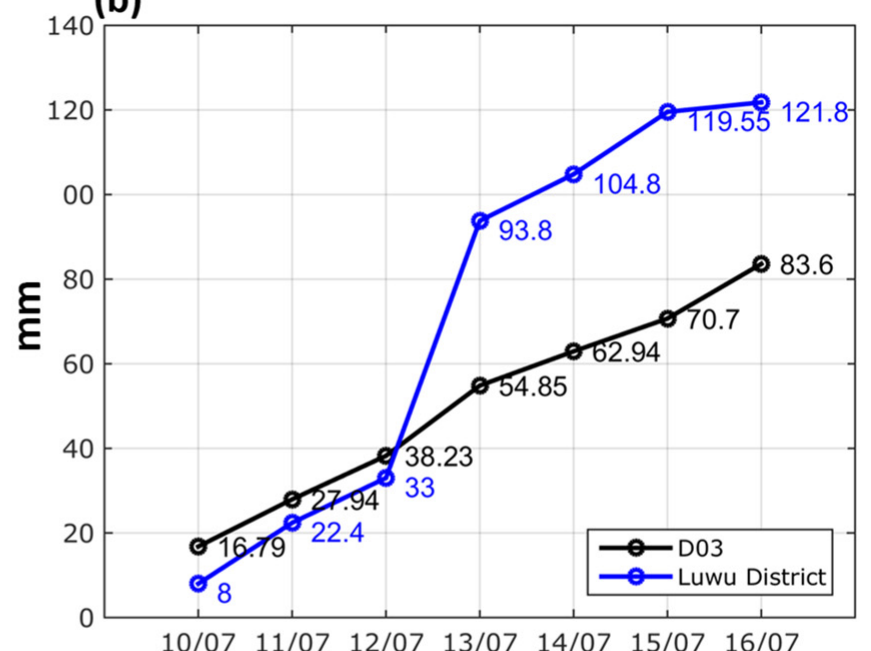

$\begin{array}{llllllll}10 / 07 & 11 / 07 & 12 / 07 & 13 / 07 & 14 / 07 & 15 / 07 & 16 / 07\end{array}$
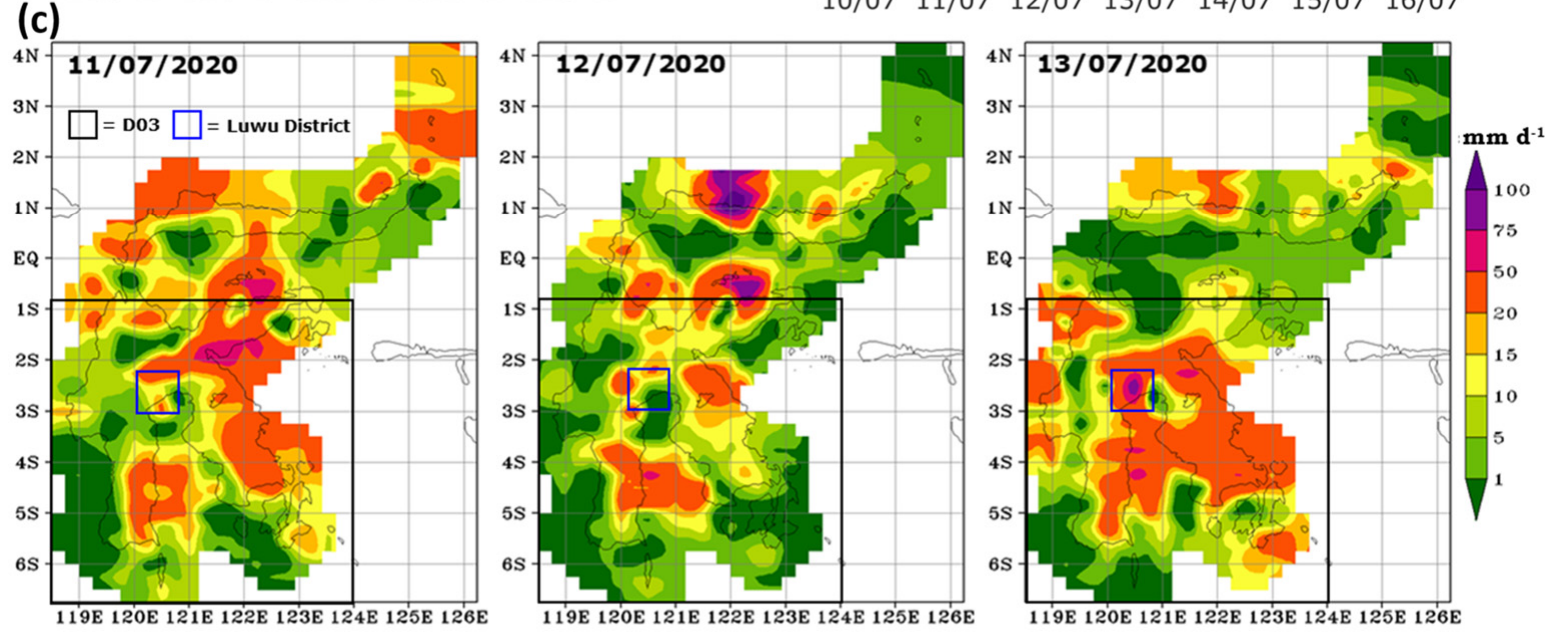

Figure 2. (a) Map of the BMKG station locations over Sulawesi Island. (b) Cumulative rainfall amount recorded at Luwu BMKG stations (blue line) and average cumulative rainfall amount computed on the D03 domain (black line) from 10 to 17 July 2020. (c) Spatial map of the interpolated cumulative daily rainfall data from several BMKG stations.

This heavy rainfall occurred in a meso-low-pressure system with anticyclonic circulation at about $100 \mathrm{~km}$ to the south of the equator over the Makassar Strait (Figure 3a). This is consistent with the study of $\mathrm{Xu}$ et al. [7], who found that regional-scale anti-cyclonic circulation existed over central-eastern $\left(4^{\circ} \mathrm{S}-6^{\circ} \mathrm{N}, 114-135^{\circ} \mathrm{E}\right)$ Indonesia at $850 \mathrm{hPa}$, corresponding to a significant convergence zone. 

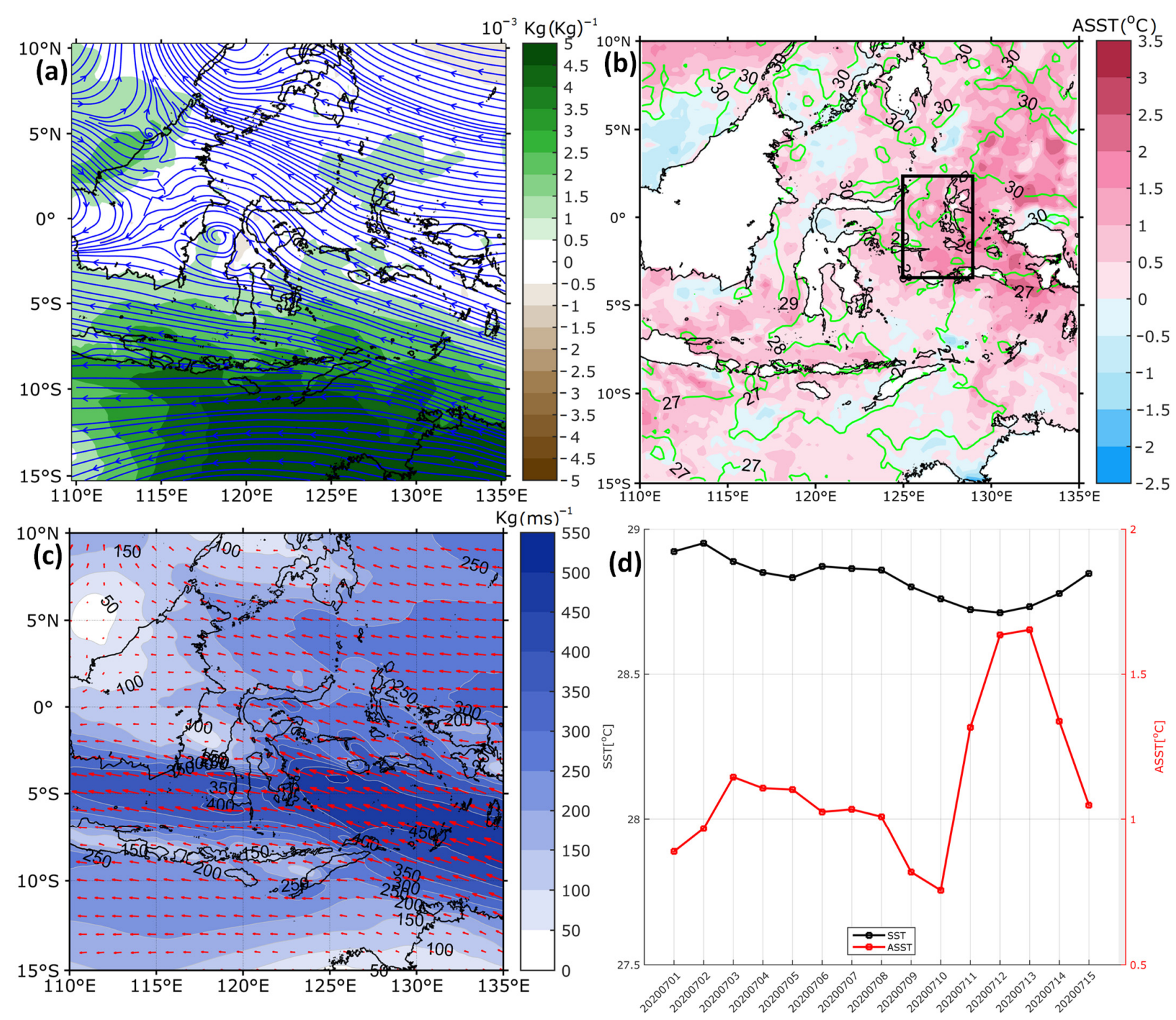

Figure 3. (a) Spatial map of specific humidity (shading) and wind at $850 \mathrm{mb}$ (streamlines) averaged from 10 to $15 \mathrm{July}$ 2020 using ERA5 data. (b) Same as (a), but for SST (contours) and the SST anomaly (shading). (c) Same as (a), but for the moisture transport integrated from 1000 to $300 \mathrm{mb}$. (d) Time series of daily SST (black) and the SST anomaly (red) averaged over the area shown by the black box in panel $(\mathbf{b})\left(3^{\circ} \mathrm{S}-2^{\circ} \mathrm{N}, 125^{\circ} \mathrm{E}-128^{\circ} \mathrm{E}\right)$ from 10 to 15 July 2020.

A low-level, humid, front-like synoptic pattern occurred over Bone Bay and a lowlevel, dry, front-like pattern passed over Luwu (Figure 3a). The humid south-easterly airflow was perpetuated by the predominantly easterly monsoon winds transporting moist air. Warm SSTs were observed over the Maluku Sea from 10 to 15 July 2020 (Figure 3c). An increase in SST $\left(>1^{\circ} \mathrm{C}\right)$ in the Maluku Sea was also recorded from 11 to 16 July 2020 (Figure 3d).

Figure S1 shows that the warm SSTs were localized in the Maluku Sea from 11 July and reached a peak around 12-13 July 2020. Zonal differences in SST anomalies between the Banda Sea and the Arafura Sea have been identified as a response to the Australian winter monsoon [6]. However, during our study period, notable SST anomalies occurred meridionally between the Maluku Sea to the north and the Banda Sea to the south.

In Figure 4, we further analyze the heavy rainfall system that led to the flash flood in Luwu on 13 July 2020 at around 20:00 Local Solar Time (LST). An MCC is clearly seen over central Sulawesi, which split into two cells (Figure 4a) and became two large rainfall systems over central and northern Sulawesi (Figure 4 b). We now consider the development 
of these two rainfall systems and their underlying causes. In particular, we assess whether the warm SSTs over the Maluku Sea provided the necessary water vapor to generate extensive convective activity.
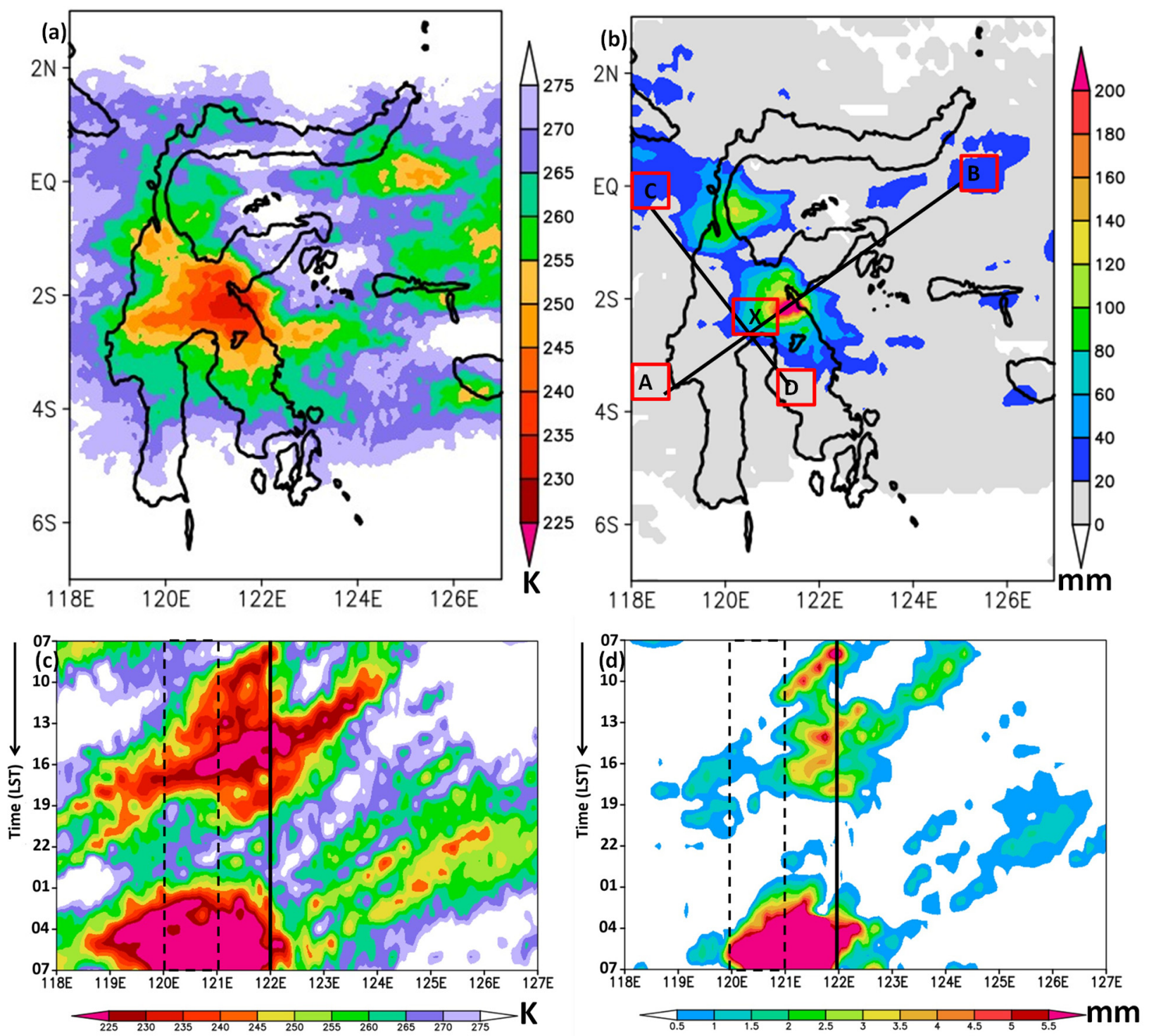

Figure 4. (a) A spatial map of the daily average of black body temperature (TBB) cloud-top height from the Himawari satellite over 13-14 July 2020. (b) Same as (a), but for the daily accumulation of precipitation from the GSMaP satellite. The A-B and C-D transects were used in further analyses in Figures S7 and S8, with the location of the points: A (3.5 $5^{\circ}$, $\left.118.5^{\circ} \mathrm{E}\right) ; \mathrm{B}\left(\mathrm{Eq}, 126^{\circ} \mathrm{E}\right) ; \mathrm{X}\left(2.5^{\circ} \mathrm{S}, 121^{\circ} \mathrm{E}\right) ; \mathrm{C}\left(0.5^{\circ} \mathrm{S}, 118^{\circ} \mathrm{E}\right) ; \mathrm{D}\left(4^{\circ} \mathrm{S}, 122^{\circ} \mathrm{E}\right)$. The ' $\mathrm{X}^{\prime}$ indicates the location of Luwu. (c) Time-longitude Hovmöller diagram of TBB cloud-top height averaged over $2^{\circ} \mathrm{S}-3^{\circ} \mathrm{S}$ (i.e., the Luwu region) from 13 to 14 July 2020 using Himawari satellite data. (d) Same as (c), but for diurnal precipitation using GSMaP satellite data. The black dashed box indicates the Luwu region $\left(120^{\circ} \mathrm{E}-121^{\circ} \mathrm{E}\right)$. The vertical solid line represents the east coast.

\subsection{Development of MCCs}

To investigate the role of SST, we consider two scenarios in our numerical model: one where the SSTs are prescribed (CTL), and one where the SSTs are updated every $6 \mathrm{~h}$. We find that only one rainfall system occurs in the CTL simulation, (Figure 5a), whereas two rainfall systems occur if the SST input in the model is updated regularly (Figure 5b). Updating the SST four times a day is also useful for reducing overestimates of precipitation intensity and spatial coverage over the ocean $\left(123^{\circ} \mathrm{E}-126^{\circ} \mathrm{E}\right)$. The updated SST scenario also refines the timing of landward convective propagation, which can be seen as a peak in 
the precipitation intensity over the coastal region on 12 July from 17:00 LST (Figure 5c) to 13 July 13:00 LST (Figure 5d).

It should also be noted that the updated SST scenario increased the precipitation intensity over the Luwu region in the early morning of 14 July from 01:00 LST to 07:00 LST (Figure 5d), which is comparable to the satellite data observations (Figure 4d). This result is consistent with Ricchi et al. [24], who demonstrated that accurate SST model inputs improve the simulation of rainfall amount and location.

The two MCCs coincided with two rainfall systems that developed in the early morning over the eastern and northern parts of central Sulawesi, and which were oriented in a southeast-northwest direction. The evolution of the convective systems over Bone Bay and the Maluku Sea was captured in both model scenarios. However, the updated SST scenario better captured the early morning convection (Figure S2). A convective system over the ocean propagated landward on 13 July from 10:00 LST to 22:00 LST (Figure 4c) and produced precipitation of low to moderate intensity on 13 July from 16:00 LST to 20:00 LST (Figure 4d).
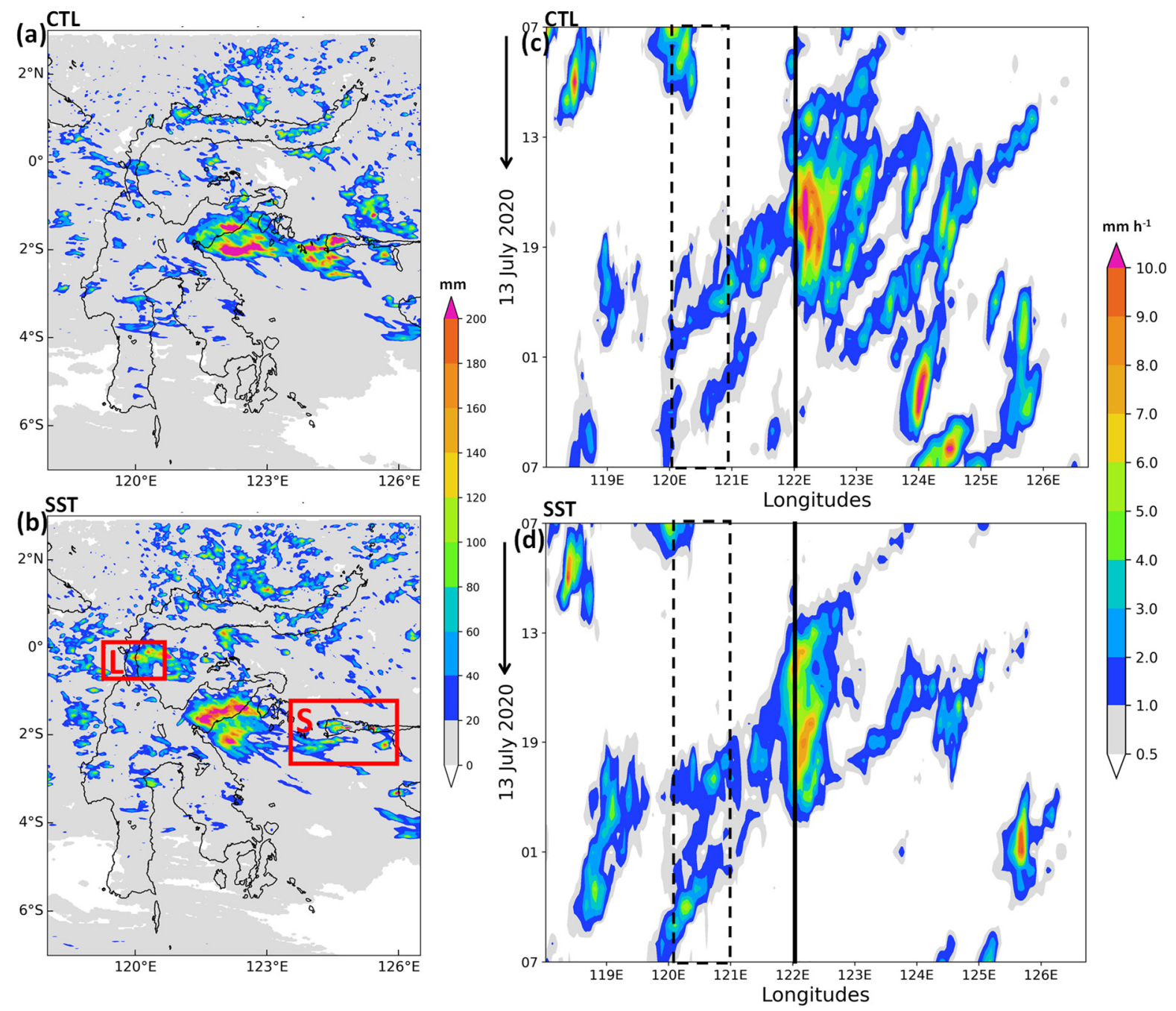

Figure 5. (a,b) Same as Figure 4b, but for simulated precipitation in the CTL and updated SST runs, respectively. (c,d) Same as Figure $4 \mathrm{~d}$, but for simulated precipitation in the CTL and updated SST runs, respectively. The red solid boxes of $\mathrm{L}\left(1^{\circ} \mathrm{S}-\mathrm{Eq} ; 119^{\circ}-121^{\circ} \mathrm{E}\right)$ and S $\left(3^{\circ} \mathrm{S}-1^{\circ} \mathrm{S} ; 124^{\circ} \mathrm{E}-126^{\circ} \mathrm{E}\right)$ were used for further analysis in Figure 6 . The black dashed boxes represent the Luwu region, whereas the vertical solid line denotes the east coastal line of central Sulawesi. 

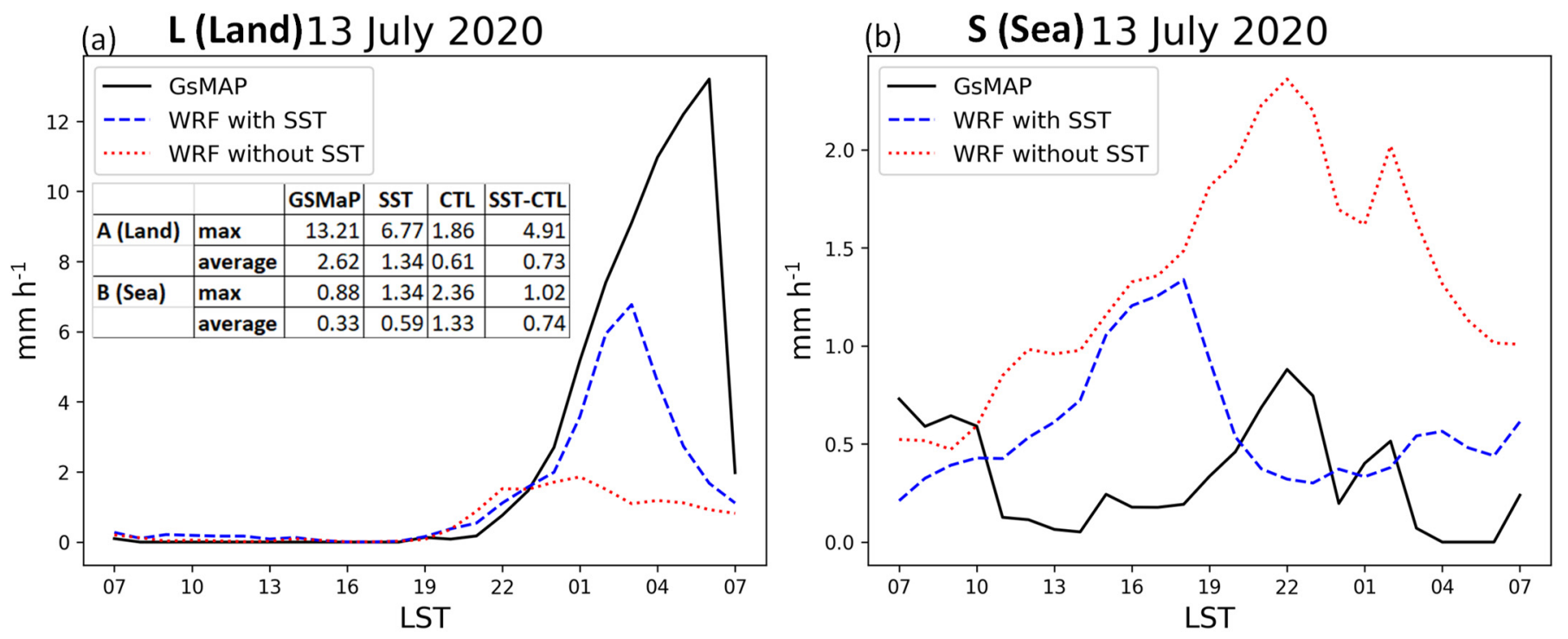

Figure 6. Comparison of simulated diurnal rainfall at D03 $(1 \mathrm{~km})$ resolution with GSMaP satellite for (a) rainfall over land $\left(\mathrm{A}, 1^{\circ} \mathrm{S}-\mathrm{Eq}, 119^{\circ} \mathrm{E}-121^{\circ} \mathrm{E}\right) ;(\mathrm{b})$ rainfall over sea $\left(\mathrm{B}, 3^{\circ} \mathrm{S}-1^{\circ} \mathrm{S} ; 124^{\circ}-126^{\circ} \mathrm{E}\right)$. The diurnal cycles of rainfall during $13-14 \mathrm{July}$ 2020 are averaged over $\mathrm{A}$ and $\mathrm{B}$ areas, as shown previously in Figure 5.

The early morning convection that developed over the Luwu region originated from the coastal convection (Figure 4c) and coincided with the precipitation peak (Figure 4d). The intensification of convection in the early morning seems to be related to the development of the pair of MCCs inland, which started on 13 July at around 23:00 LST (Figures S5 and S6). The pair of MCCs became stronger between 22:00 LST and 07:00 LST at $3^{\circ} \mathrm{S}-2^{\circ} \mathrm{S}$ and $0^{\circ}$ $1^{\circ} \mathrm{S}-\mathrm{Eq}$ (Figure $5 \mathrm{a}$ ), leading to a pair of rainfall systems (Figure $5 \mathrm{~b}$ ).

These features are reproduced qualitatively in the updated SST scenario (Figure 5d). Quantitatively, we need to test the model performance of simulated rainfall in intensity, timing, duration, and location by comparing simulated and observed rainfall. Because the updated SST scenario improved simulated rainfall by increasing rainfall over land (L) and decreasing over the sea (S) (Figure $5 b$ ), we selected both regions for further quantitative analysis in Figure 6.

Figure 6a clearly showed that both simulated rainfalls have the same initial convection time at 19:00 LST on 13 July 2020. Those initial rainfall times were simulated two hours early compared to the observed rainfall. However, the simulated rainfall in the updated SST scenario performed better than the CTL in capturing the maximum intensity, and significantly increased the rainfall by $\sim 5 \mathrm{~mm}$. In addition, the SST scenario is capable of simulating a lead time of rapid rainfall onset at 21:00 LST on 13 July 2020, whereas the CTL seems to have failed to capture the accelerated convection process. This precise rapid rainfall onset helped improve the forcing input for the real-time precipitation-runoff forecasting models over the catchment area [25-27]. Interestingly, the distinction time of maximum intensity between the SST scenario and GSMaP satellite is also two hours, consistent with the previous study conducted under the same model configurations [18].

For the sea region (Figure 6b), the updated SST scenario also improves simulated rainfall by reducing the intensity by about $1 \mathrm{~mm}$. However, the CTL could reproduce the diurnal rainfall phase well, while the updated SST scenario was exhibited as out of phase at maximum intensity. In this case, the time of reaching maximum intensity was four hours earlier than in the satellite observation. Thus, this finding that updating SST in numerical weather predictions may change the time of evolution of heavy rainfall by modulating evaporation and modifying the stability of the low-level atmosphere is consistent with previous works [24].

It is important to note that rapid rainfall over North Sulawesi (L) (Figure 6b) may be related to the existence of double MCCs, which has been clearly shown as an intensification 
of both cloud and precipitation from 22:00 LST on 13 July 2020 to 07:00 LST on 14 July 2020 (Figure 7a,b). Again, the CTL greatly underestimates (Figure 7c) the double MCCs, whereas the SST scenario could simulate this with good agreement (Figure 7d). Interestingly, those night-to-morning oceanic convection systems also seem to be connected to the landbased convection system in the Luwu region from 07:00 LST to 19:00 LST on 13 July 2020 (Figure 7a,b). The strong connection between land-based and sea-based convection systems corresponds to the characteristics of coastal precipitation, which are described by a strong propagation of convection systems [28]. In this case study, the persistent rainfall across the Luwu region during the daytime on 13 July 2020 possibly triggered the flash flood at 20:00 LST.
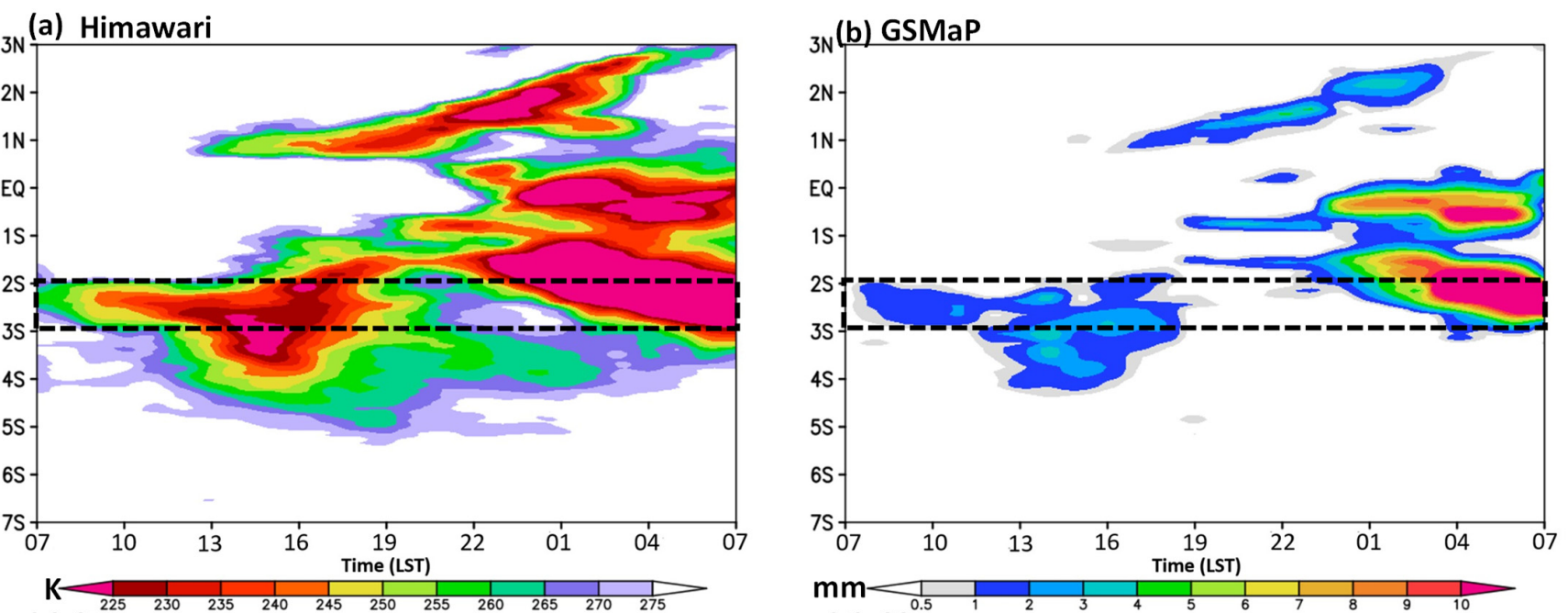

\section{(c) $\mathrm{CTL}^{225}$}

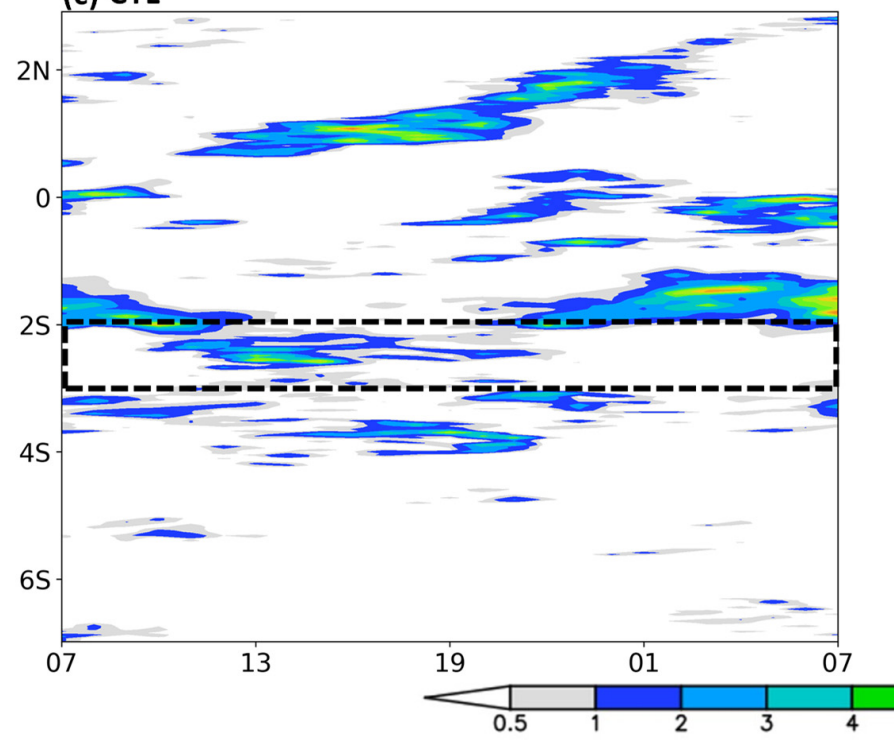

\section{(d) SST}

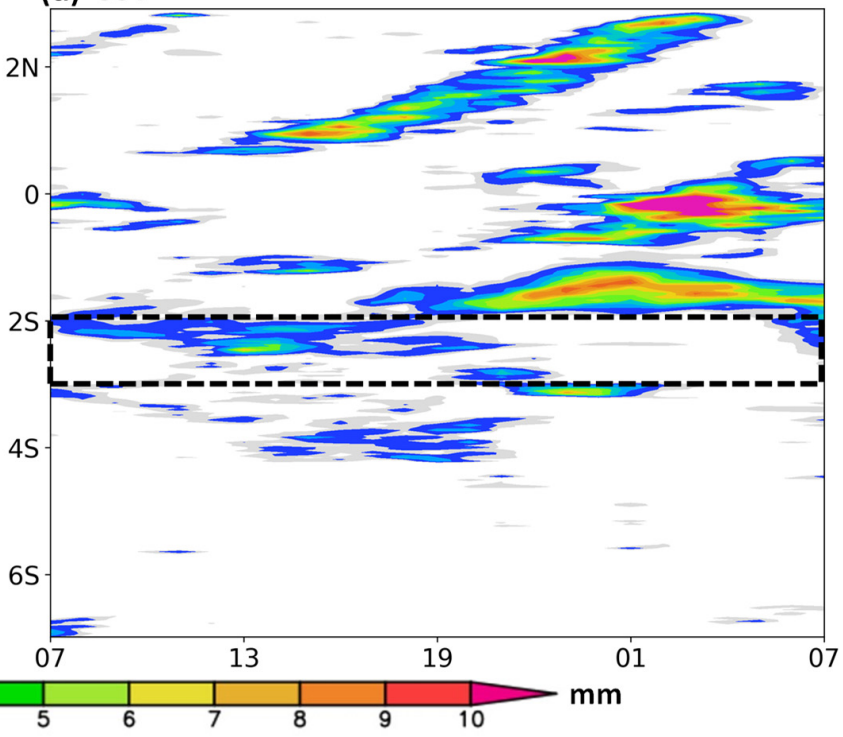

Figure 7. Latitude-time Hovmöller diagram averaged over $120^{\circ} \mathrm{E}-121^{\circ} \mathrm{E}$ (i.e., the Luwu region) from 13 to $14 \mathrm{July} 2020$ for (a) blackbody temperature (TBB) using Himawari satellite data; (b) precipitation observed by the GSMaP satellite; (c) precipitation simulated in the CTL run; (d) precipitation simulated in the updated SST run. The black dashed box indicates the Luwu region $\left(2^{\circ} \mathrm{S}-3^{\circ} \mathrm{S}\right)$.

Because the flash flood that occurred over Luwu was associated with late afternoon rainfall, we need to verify whether the initial convection came from the Maluku Sea or Bone Bay, given the predominantly southeasterly monsoon winds. In a previous figure (Figure 5), it has been shown that the convective system intensified over Bone Bay and the southern coastal region of Luwu on 12 July 2020. Nonetheless, the convection was still weak. A small convective system started to develop in the early morning (01:00 LST) of 
13 July 2020 over the Maluku Sea near the eastern coastal region of central Sulawesi. This then extended to a wider region over Luwu and the surrounding areas in the late afternoon (19:00 LST; Figure 5). The intensification of convective activity over the Luwu region from late afternoon until midnight was more strongly influenced by convection over the Maluku Sea (Figure 8) than over Bone Bay (Figure S7).
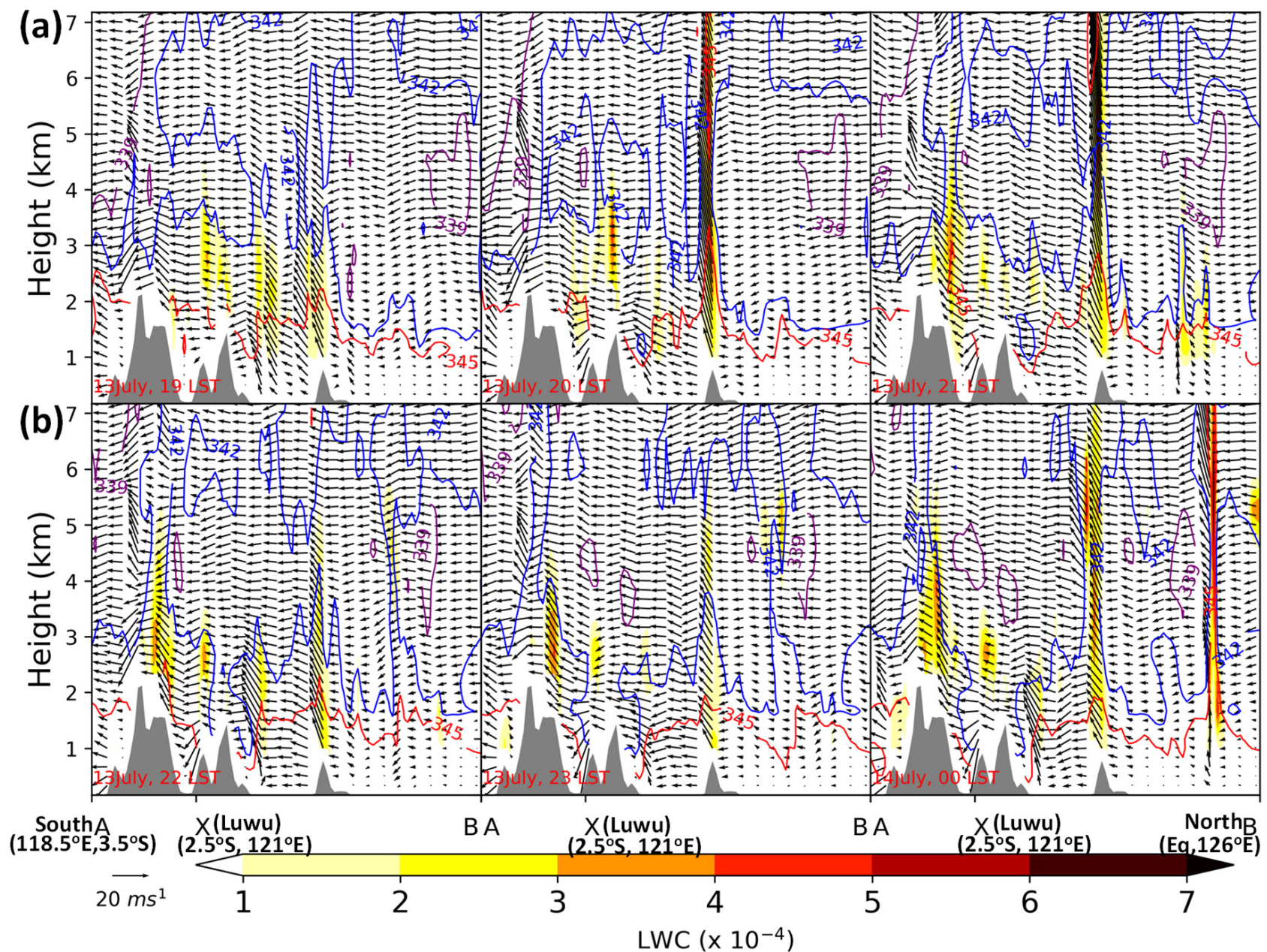

Figure 8. Height-latitude cross-sections of wind (vectors; vertical component multiplied by a factor of 40), cloud mixing ratio (shading), and equivalent potential temperature anomaly (contours) on 13 July 2020 for (a) 19:00-21:00 LST and (b) 22:00-00:00 LST. The ' $X$ ' indicates the location of Luwu. For clarity, the equivalent potential temperature has had $343 \mathrm{~K}$ subtracted from it, with blue (red) lines indicating negative (positive) values. The contour interval is $1.5 \mathrm{~K}$. The A-B transect refer to point locations in Figure $4 \mathrm{~b}$.

The convection intensified and was maintained by a cold pool, which was initiated at 20:00 LST by near-surface (1 km altitude) cold airflow over eastern Luwu (Figure 8a). The cold pool further developed, deepened, and extended over Luwu, helping to maintain the precipitation systems over both the eastern and western parts of Luwu. The cold pool associated with the MCCs and the convection system propagating landward [29] as well as offshore [18] may also have triggered the heavy rainfall over the coastal region of Sumatra, Indonesia. In this case, when a cold pool developed in a large area over the Luwu region (Figure 8 b) at 22:00-00:00 LST, deep moist convection $(>7 \mathrm{~km}$ ) evolved over the ocean $\left(\mathrm{B} ; \mathrm{Eq}, 126^{\circ} \mathrm{E}\right)$ under a back-building mechanism. This mechanism seems to be strongly influenced by the moistening of the boundary layer as a result of warming SST. This was also confirmed by the CTL simulation, which failed to display the features of oceanic convection under the back-building mechanism (see Figure S8). 
Again, the cold pool over Luwu indirectly strengthened the convective system, which grew extensively via the back-building mechanism over the Maluku Sea on 14 July at 06:00 LST (Figure 9), which did not exist in the CTL simulation (see Figure S9). The back-building mechanism was identified as quasi-stationary, southeast-northwest double convective cells, which were initiated on 13 July from 22:00 LST and became mature the following day at 07:00 LST, further dissipating until 10:00 LST (see Figures S5-S7). The back-building mechanism was previously found as a common characteristic of MCSs in the midlatitudes [30-33], related to extreme rainfall production [34] that can be regulated by large-scale ascent and maintained by the cold pools from the outflow [18,34].

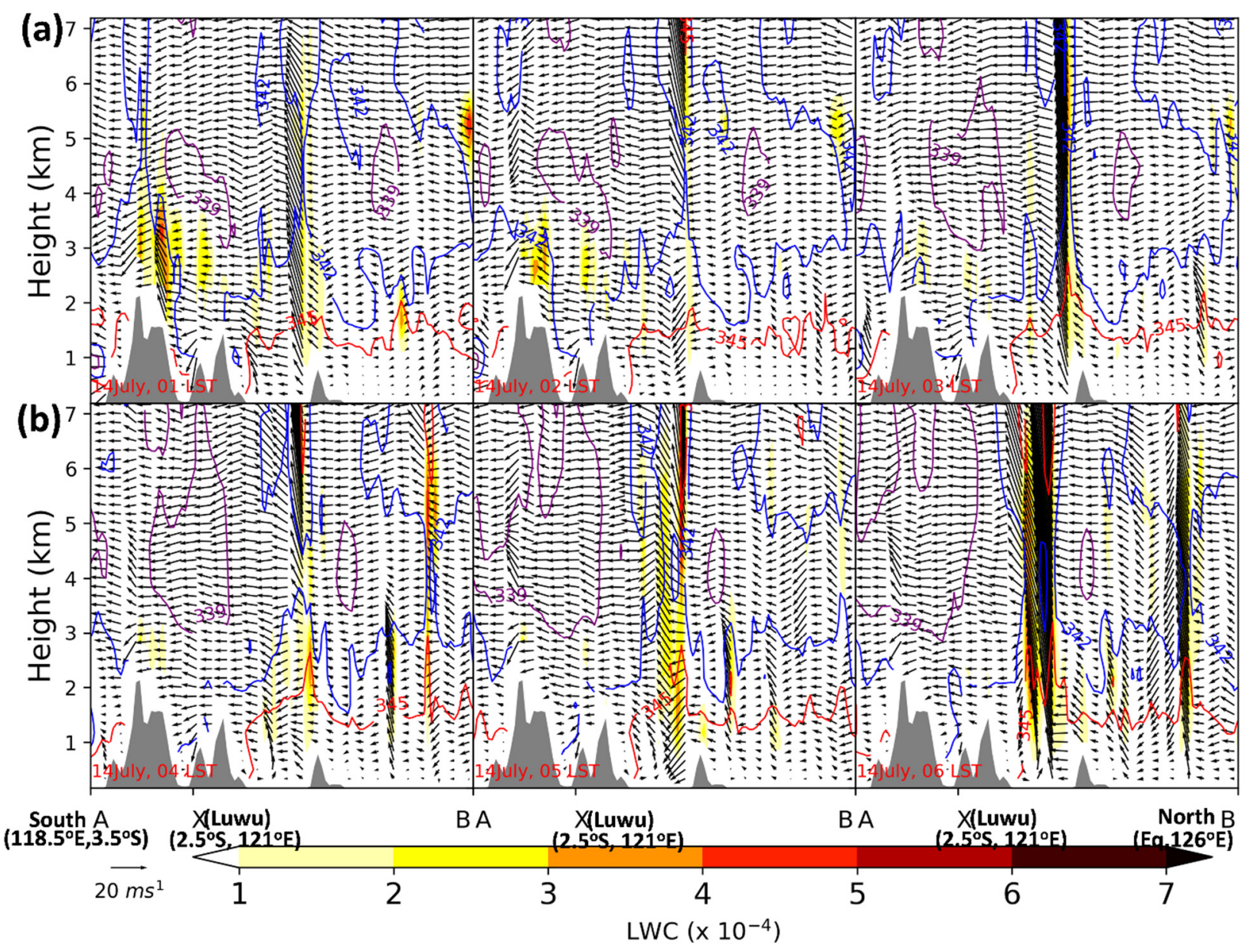

Figure 9. Same as Figure 8, but for (a) 01:00-03:00 LST and (b) 04:00-06:00 LST 14 July 2020.

However, Bone Bay also played a role in providing warm, moist airflow near the surface, ultimately producing a warm front where the easterly airflow was met with cold, dry air (Figure 10). The dynamic processes leading to the heavy rainfall outlined in this study are in accordance with previous studies [24,34]. In particular, the warm front, cold pool, and back-building mechanism helped to generate this long-lasting rainfall system. It is interesting to note that the strong south-easterly monsoon (see: Figure 3a,b) has a small contribution in controlling the large system of MCCs due to the slow-motion and quasi-stationary characteristics of the convective system. However, the role of monsoons is to provide an environment to support the stationary nature of the warm front (Figure 10). 


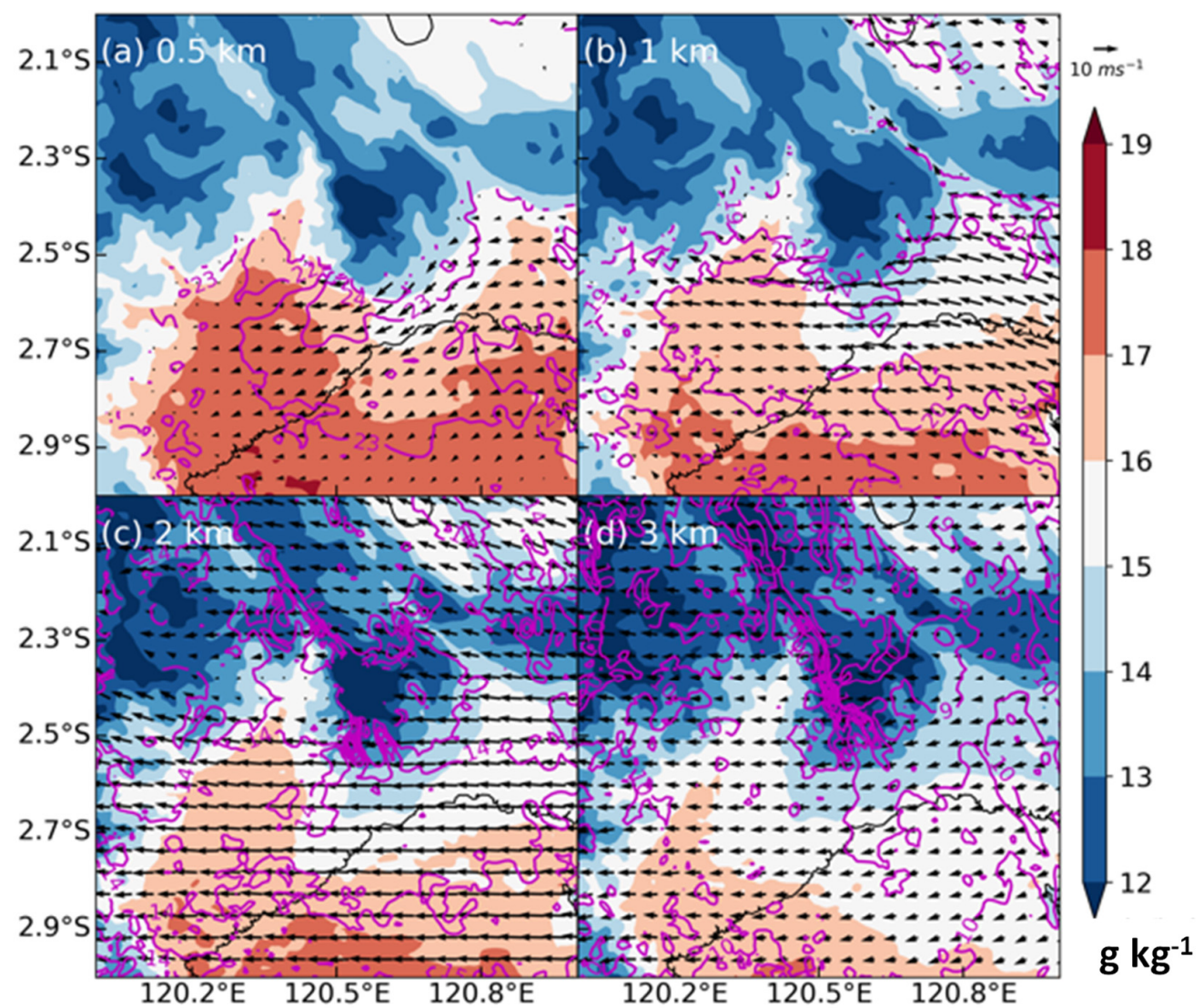

Figure 10. Horizontal distribution of temperature (contours) and water vapor mixing ratio (shading) simulated by the WRF model at $1 \mathrm{~km}$ resolution and averaged over 13 July 2020 (19:00-00:00 LST) at an altitude of (a) $0.5 \mathrm{~km},(\mathbf{b}) 1 \mathrm{~km},(\mathbf{c}) 2 \mathrm{~km}$, and (d) $3 \mathrm{~km}$.

\section{Conclusions}

We investigated factors that might have influenced the heavy rainfall associated with a major flash flood in Luwu, Sulawesi, using experiments with a WRF model at $1 \mathrm{~km}$ resolution, by comparing results with and without updating SST. The flash flood that occurred at around 20:00 LST was triggered by persistent moderate rainfall from morning to night across Luwu. Our results confirmed that the warm SSTs over the Maluku Sea provided abundant water vapor and intensified the convective systems over the ocean that propagated south-westward around Luwu. The interaction between north-easterly, low-level, humid airflow and the elevated terrain over Luwu led to the development of a stationary cold pool at around $1 \mathrm{~km}$ latitude and helped to maintain the rainfall systems over both the mainland and ocean. These findings are in accordance with previous studies demonstrating that a humid airflow near the surface may rise over a cold pool near a mountain range and reinforce heavy rainfall over coastal regions [34].

This study also found interesting features related to the development of a pair of longlasting MCCs and a double rainfall system on 13 July from 22:00 LST to 14 July 07:00 LST over the northern parts of central Sulawesi ( $3^{\circ} \mathrm{S}-2^{\circ} \mathrm{S}$ and $\left.1^{\circ} \mathrm{S}-\mathrm{Eq}\right)$. The double rainfall system was reproduced in the model simulation with updated SSTs. The simulated rainfall confirmed that the double rainfall system developed via a back-building mechanism, which was maintained by a stationary cold pool and a warm front. This back-building mechanism helped form a long-lasting, quasi-stationary convective system $(>10 \mathrm{~h})$, which is consistent with previous studies [30-33], stating that it developed along mesoscale boundaries and was maintained by storm outflows. However, the night-to-morning MCCs over Sulawesi showed an exceptional MCC from both continental and oceanic MCS characteristics in the Pacific Northwest region, described in a previous study [14]. 
On the other hand, the warm front was generated by warm and moist airflow near the surface $(0.5-3 \mathrm{~km})$ over Bone Bay in the southern part of Luwu. This was initiated due to the warm SSTs near the coastal region. The long-lasting MCCs then developed as a response to both the warm front and back-building mechanism. The improved prediction of rainfall in the updated SST scenario is consistent with previous studies indicating that SST distribution plays a fundamental role in having an accurate oceanic boundary layer energy budget, which is essential for predicting rainfall [24].

In terms of the hydro-meteorological disaster over eastern Indonesia, this study suggests that numerical weather predictions of heavy rainfall events could be improved by using high spatial resolution and by updating the SSTs. Due to limited observation in the region, this relatively simple technique in the WRF model provided a new strategy to improve output product quality, which is helpful in producing better input for the hydrological model. However, it is important to note that the location of the double rainfall system in this study differed between the simulation and observations. The process for determining the precise position of the double rainfall system should be a subject of future investigation.

Supplementary Materials: The following are available online at https://www.mdpi.com/article/10 .3390 /atmos12111445/s1, Figure S1: Spatial maps of daily sea surface temperature, Figure S2: Spatial map of the 6-hourly evolution of surface winds and precipitation, Figure S3: Spatial maps of the 6-hourly evolution of simulated precipitation, Figure S4: Same as Figure S3, but for the 3-hourly evolution of precipitation from the GSMaP satellite, Figure S5: Same as Figure S4, but for Black Body Temperature (TBB), Figure S6: Same as Figure S4, but for the hourly evolution of TBB, Figure S7: Height-latitude cross-sections of wind (vectors; vertical component multiplied by a factor of 40), cloud mixing ratio (shading), and equivalent potential temperature anomaly (contours) on 13 July 2020, Figure S8: Same as Figure 8, but for CTL simulation, Figure S9: Same as Figure 9, but for CTL simulation.

Author Contributions: E.Y. and D.E.N. are the main contributors. Conceptualization, E.Y.; methodology, D.E.N.; validation, T. and R.M.; formal analysis, E.Y.; writing-original draft preparation, E.Y.; writing-review and editing, E.Y. and D.E.N.; visualization, D.E.N., T. and R.M.; funding acquisition, E.Y. All authors have read and agreed to the published version of the manuscript.

Funding: This research was funded by the Indonesia Educational Endowment Fund (LPDP) through the Mandatory Productive Innovative Research program under National Research Priority [252/ Menteri Ristek/Ka BRIN/E1/PRN/2020].

Institutional Review Board Statement: Not applicable.

Informed Consent Statement: Not applicable.

Data Availability Statement: The datasets of NCEP-FNL, Himawari, GSMaP, BMKG, and ERA5 are publicly available in the permanent archives: https:/ / doi.org/10.5065/D6M043C6 (accessed on 18 October 2021) [19], http://weather.is.kochi-u.ac.jp/ (accessed on 18 October 2021) [20], ftp:/ / rainmap:Niskur+1404@hokusai.eorc.jaxa.jp / (accessed on 18 October 2021) [21], https:/ / doi. org/10.1175/JCLI-D-16-0575.1 (accessed on 18 October 2021) [22], and https:/ / doi.org/10.24381 /cds.adbb2d47 (accessed on 18 October 2021) [23], respectively.

Acknowledgments: The authors thank the BMKG for supporting station data observations. This research supports the international program of Years of the Maritime Continent (YMC) of 2017-2021 and the improvement of the forecasting product of the Satellite-based Disaster Early Warning System (SADEWA) of Center of Atmospheric Research and Technology. The authors are very grateful to Anthony R. Lupo, academic editor of Atmosphere, and two anonymous reviewers for their constructive comments and suggestions, which substantially improved the clarity of this work.

Conflicts of Interest: The authors declare no conflict of interest. 


\section{References}

1. Hapuarachchi, H.A.P.; Pagano, T.C.; Wang, Q.J. A review of advances in flash flood forecasting. Hydrol. Process. 2011, 25, 2771-2784. [CrossRef]

2. Gourley, J.J.; Clark, R.A., III. Real-time flash flood forecasting. In Oxford Encyclopedia of Natural Hazard Science; Oxford University Press: Oxford, UK, 2018. [CrossRef]

3. Nasional.Kompas.com. Available online: https://nasional.kompas.com/read/2020/07/20/09210791/bnpb-ungkap-tigapenyebab-banjir-bandang-di-luwu-utara?page=all (accessed on 27 August 2021).

4. Chang, C.-P.; Wang, Z.; McBride, J.; Liu, C.-H. Annual cycle of Southeast Asia-Maritime Continent rainfall and the asymmetric monsoon transition. J. Clim. 2005, 18, 287-301. [CrossRef]

5. Aldrian, E.; Susanto, R.D. Identification of three dominant rainfall regions within Indonesia and their relationship to sea surface temperature. Int. J. Climatol. 2003, 23, 1435-1452. [CrossRef]

6. Kida, S.; Richards, K.J. Seasonal Sea surface temperature variability in the Indonesian Seas. J. Geophys. Res. 2009, 114, C06016. [CrossRef]

7. Xu, Q.; Guan, Z.; Jin, D.; Hu, D. Regional characteristics of interannual variability of summer rainfall in the Maritime Continent and their related anomalous circulation patterns. J. Clim. 2019, 32, 4179-4192. [CrossRef]

8. Lee, H. General rainfall patterns in Indonesia and the potential impacts of local seas on rainfall intensity. Water 2015, 7, 1751-1768. [CrossRef]

9. Villafuerte, M.Q.; Matsumoto, J. Significant influences of global mean temperature and ENSO on extreme rainfall in Southeast Asia. J. Clim. 2015, 28, 1905-1919. [CrossRef]

10. Lestari, S.; Hamada, J.-I.; Syamsudin, F.; Sunaryo; Matsumoto, J.; Yamanaka, M.D. ENSO influences on rainfall extremes around Sulawesi and Maluku islands in the eastern Indonesian Maritime Continent. SOLA 2016, 12, 37-41. [CrossRef]

11. Supari; Tangang, F.; Salimun, E.; Aldrian, E.; Sopaheluwakan, A.; Juneng, L. ENSO modulation of seasonal rainfall and extremes in Indonesia. Clim. Dyn. 2016, 51, 2559-2580. [CrossRef]

12. Cai, W.; Wang, G.; Santoso, A.; McPhaden, M.J.; Wu, L.; Jin, F.-F.; Timmermann, A.; Collins, M.; Vecchi, G.; Lengaigne, M.; et al. Increased frequency of extreme La Niña events under greenhouse warming. Nat. Clim. Chang. 2015, 5, 132-137. [CrossRef]

13. Takahashi, H.G. Seasonal and diurnal variations in rainfall characteristics over the tropical Asian monsoon region using TRMM-PR Data. SOLA 2016, 12A, 22-27. [CrossRef]

14. Liu, C.; Shige, S.; Takayabu, Y.N.; Zipser, E. Latent heating contribution from precipitation systems with different sizes, depths, and intensities in the tropics. J. Clim. 2015, 28, 186-203. [CrossRef]

15. National Research Council. Flash flood forecasting over complex terrain: With an assessment of the sulphur mountain NEXRAD in southern California: Flash Floods. Natl. Acad. Press. 2005, 12-25. [CrossRef]

16. Skamarock, W.C.; Klemp, J.B.; Dudhia, J.; Gill, D.O.; Barker, D.M.; Duda, M.G.; Huang, X.-Y.; Wang, W.; Powers, J.G. A Description of the Advanced Research WRF Version 3; Mesoscale and Microscale Meteorology Division, National Center for Atmospheric Research: Boulder, CO, USA, 2008; p. 126.

17. Fonseca, R.M.; Zhang, T.; Yong, K.-T. Improved simulation of precipitation in the tropics using a modified BMJ scheme in the WRF model. Geosci. Model Dev. 2015, 8, 2915-2928. [CrossRef]

18. Yulihastin, E.; Trismidianto; Nuryanto, D.E. Convective cold pool associated with offshore propagation of convection system over the east coast of southern Sumatra. Adv. Meteorol 2021, 2021, 1-13. [CrossRef]

19. Kalnay, E.; Kanamitsu, M.; Kistler, R.; Collins, W. The NCEP/NCAR 40-year reanalysis project. Bull. Am. Meteorol. Soc. 1996, 77, 437-472. [CrossRef]

20. Besselaar, E.J.M.; Schrier, G.; Cornes, R.C.; Iqbal, A.S.; Klein, T.A.M.G. SA-OBS: A daily gridded surface temperature and precipitation dataset for Southeast Asia. J. Clim. 2017, 30, 5151-5165. [CrossRef]

21. Kubota, T.; Shige, S.; Hashizume, H.; Aonashi, K.; Takahashi, N.; Seto, S.; Hirose, M.; Takayabu, Y.N.; Ushio, T. Global precipitation map using satellite-borne microwave radiometers by the GSMaP project: Production and validation. IEEE Trans. Geosci. Remote Sens. 2007, 45, 2259-2275. [CrossRef]

22. Bessho, K.; Date, K.; Hayashi, M.; Ikeda, A.; Imai, T.; Inoue, H.; Kumagai, Y.; Miyakawa, T.; Murata, H.; Ohnoo, T.; et al. An introduction to Himawari-8/9- Japan's new-generation geostationary meteorological satellites. J. Meteorol. Soc. Jpn. 2016, 94, 151-183. [CrossRef]

23. Hersbach, H.; Bell, B.; Berrisford, P.; Hirahara, S.; Horányi, A.; Muñoz-Sabater, J.; Nicolas, J.; Peubey, C.; Radu, R.; Schepers, D.; et al. The ERA5 global reanalysis. Q. J. R. Meteorol. Soc. 2020, 146, 1999-2049. [CrossRef]

24. Ricchi, A.; Bonaldo, D.; Cioni, G.; Carniel, S.; Miglietta, M.M. Simulation of a flash-flood event over the Adriatic Sea with a high-resolution atmosphere-ocean-wave coupled system. Sci. Rep. 2021, 11, 9388. [CrossRef]

25. Amengual, A.; Carrió, D.S.; Ravazzani, G.; Homar, V. A Comparison of ensemble strategies for flash flood forecasting: The 12 october 2007 case study in Valencia, Spain. J. Hydrometeorol. 2017, 18, 1143-1166. [CrossRef]

26. Muñoz, P.; Orellana-Alvear, J.; Willems, P.; Célleri, R. Flash-flood forecasting in an Andean mountain catchment-development of a step-wise methodology based on the random forest algorithm. Wate 2018, 10, 1519. [CrossRef]

27. Roux, H.; Amengual, A.; Romero, R.; Bladé, E.; Sanz-Ramos, M. Evaluation of two hydrometeorological ensemble strategies for flash-flood forecasting over a catchment of the eastern Pyrenees. Nat. Hazards Earth Syst. Sci. 2020, 20, 425-450. [CrossRef] 
28. Yulihastin, E.; Hadi, T.W.; Ningsih, N.S.; Syahputra, M.R. Early morning peaks in the diurnal cycle of precipitation over the northern coast of West Java and possible influencing factors. Ann. Geophys. 2020, 38, 231-242. [CrossRef]

29. Trismidianto; Hadi, T.W.; Ishida, S.; Moteki, Q.; Manda, A.; Iizuka, S. Development processes of oceanic convective systems inducing the heavy rainfall over the western coast of Sumatra on 28 October 2007. SOLA 2016, 12, 6-11. [CrossRef]

30. Schumacher, R.S.; Johnson, R.H. Organization and environmental properties of extreme-rain-producing mesoscale convective systems. Mon. Weather Rev. 2005, 133, 16. [CrossRef]

31. Wang, X.; Cui, C.; Cui, W.; Shi, Y. Modes of mesoscale convective system organization during meiyu season over the Yangtze river basin. J. Meteorol. Res. 2014, 28, 111-126. [CrossRef]

32. Schumacher, R.S.; Rasmussen, K.L. The formation, character and changing nature of mesoscale convective systems. Nat. Rev. 2020, 1, 300-314. [CrossRef]

33. Luo, Y.; Gong, Y.; Zhang, D.-L. Initiation and Organizational Modes In An Extreme-Rain-Producing Mesoscale Convective System along A Meiyu Front In East China. Mon. Weather Rev. 2014, 142, 203-221. [CrossRef]

34. Seko, H.; Hayashi, S.; Kunii, M.; Saito, K. Structure of the Regional Heavy Rainfall System that Occurred in Mumbai, India, on 26 July 2005. SOLA 2008, 4, 129-132. [CrossRef] 